\title{
The Correlation Between Students' Creativity And Their Writing Skill At Ma NW Peseng
}

\author{
Agus Salim ${ }^{1}$, Tawali' ${ }^{2}$, Sudirman $^{3}$, Wari'ah $^{4}$ \\ ${ }^{1234}$ Fakultas Budaya, Manajemen, dan Bisnis \\ agussalim@ikipmataram.ac.id
}

\begin{abstract}
This research was aimed to find out the correlation between students' creativity and their writing skill. The kind of this research was simple correlational study (quantitative approach). The population of this research was 77 of the second grade students of MA NW Peseng. The sample of this research was 21 consist of one class. The sample technique that used in this research was cluster random sampling technique by using lottery. The intruments that was used in this research were tests, that were verbal creativity test and writing test. Then the technique that used in analyzing the data was Pearson Product Moment formula. From the research, the $r$ of xy score was higher than r-table (0.829>0.456) in 5\% and $1 \%$ level of significance. Based on the result of this research, it could be concluded that there was a significant correlation between students' creativity and their writing skill meant Alternative Hypothesis (Ha) was accepted and Null hypothesis $(\mathrm{HO})$ was rejected.
\end{abstract}

Key word: Students' Creativity, Writing Skill, and Correlational Study.

Abstrak. Penelitian ini bertujuan untuk mengetahui hubungan antara kreatifitas siswa dan kemampuan menulis siswa. Jenis penelitian ini adalah penelitian hubungan (pendekatan kuantitatif). Populasi dari penelitian ini adalah 77 siswa kelas dua MA NW Peseng. Sampel dari penelitian ini adalah 21siswa yang terdiri dari satu kelas. Teknik pengambilan sampel yang digunakan dalam penelitian ini adalah teknik cluster random sampling. Instrumen yang digunakan dalam penelitian ini adalah tes; tes verbal kreatifitas dan tes menulis. Kemudian teknik yang digunakan untuk menganalisis data adalah rumus Pearson Product Moment. Dari data penelitian ditemukan bahwa skor $\mathrm{r}$ xy lebih tinggi dari tabel $\mathrm{r}(0.829>0.456)$ dalam level signifikansi 5 dan $1 \%$. Berdasarkan hasil penelitian ini, dapat disimpulkan bahwa terdapat hubungan nyata antara tingkat kreatifitas siswa dan kemampuan menulis mereka yang berarti Hipotesis Alternatif (Ha) diterima dan Hipotesis Nol (H0) ditolak.

Kata Kunci: Kreatifitas Siswa, Kemampuan Menulis, dan Penelitian Hubungan.

\section{INTRODUCTION}

\section{Backgraound of Study}

Writing is one of four importance skills in the language. Through writing, students can convey and express their ideas, opinion, and feeling in written form. According to Heaton (1988:135), the writing skills are complex and sometimes difficult to teach, requiring mastery not only of grammatical and rhetorical devices but also of conceptual and judgment elements. The conceptual and judgment elements included language use, mechanical skill, treatment and content, stylistic skill, judgment skill, and etc. it means, the result of the writing process can be good, when a writer follows the rule and the judgments of writing skill. Beside influenced by the rules and the judgments of writing skill, writing also influenced by some considerations. Creativity is one of the considerations. According to Kate Granville (2001) in Syamsul Khoir (2015: 1), writing constitutes an activity which involves and utilizes some imagination and creativity. Furthermore, John Langan (2001) in Syamsul Khoir (2015: 1) wrote that writing is not only an activity in which one holds a pen or pencil and writes a series of words down into a piece of paper, but it is also deemed as a cognitive activity in which creativity is required. According to Joe Y. F. Lau (2011: 215) and Margaret A. Boden (2004: 
1), creativity is new ideas that inspired by old one's theory, view, or finding which recombined with a few ideas to get new ones are new, surprising and valuable. Based on the problem above, researcher concluded that Creativity was one of some aspects that influence their writing.

Creativity is an ability of human being in producing, developing, or creating ideas. By having creativity, students can write any topics, anytime, and anywhere. Creativity can make your writing unlimited in topic, place and time. Creativity aspect in writing also are able to gain readers' and writers' imagination, feeling, sense and interest that make writer or reader will cry, smile, happy, sad, or the other feelings when they are reading or writing. By knowing this phenomenon, writer tried to find out the correlation between students' creativity and their writing skill.

This research was intended to know whether there was or not the correlation between students' creativity and their writing skill at second grade student of MA NW Peseng in Academic Year 2019/2020, that expected be useful for some significances;

1. Theoretical significance

a. This research was expected to be useful to provide theoretical information about creativity, writing skill, and the correlation between students' creativity and their writing skill.

b. For the next researcher, this study was expected to be useful for the references to conduct the next research in the future.

2. Practical significance

a. For teacher, the result of this research was expected to be useful to help study and learning process by knowing the creativity, writing skill and the correlation between students' creativity and their writing skill For the researcher of this study, the result of this research was expected to give information about the correlation of students' creativity and their writing skill. So, as a candidate of a teacher the researcher will have knowledge about it that will be useful in the future.

\section{RESEARCH METHOD}

\section{Reseach design}

The Correlational study was used in this study which is included as a quantitative research. Correlation is a research design that aims to find the relationship between two variables. In correlation studies, we are interested in the strength of the linear relationship between the two variables, so we estimate the correlation coefficient, make statistical inference about it, and see how the variability in the experiment is affected by association between the variables (Shirley Dowdy et al, 2004:239). Therefore, in this study researcher will use correlational method to Therefore, in this study researcher will use correlational method to find out the relationship between students' creativity and their writing short story skill and the kind of the correlation in this study is simple correlational study. Where a researcher had one independent and dependent variables that want to be measured its correlation.

\section{Population and Sample}

The population in this research was the second grade student of Ma Nw Peseng which consisted of 77 from 3 classes; 11 IPS A $=21$ students, 11 IPS $B=27$ students, and 11 IPS C $=$ 29 students. From the population, by using cluster random sampling researcher got A class which consisted of 21 students as the sample of this research.

\section{Techniques of Data Collection}

There were two tests that used in collecting the data; verbal creativity test from Utami Munandar (2012) and writing test.

\section{Techniques of Data Analysis}

The techniques of data analysis that used in this study are:

1. The use of Karl Pearson's coefficient of correlation (simple correlation).

The formula for $r$ (Karl Pearson's coefficient of correlation)

$$
r=\frac{\Sigma X Y-\frac{(\Sigma X)(\Sigma Y)}{N}}{\sqrt{\left(\Sigma X^{2}-\frac{(\Sigma X)^{2}}{N}\right)\left(\Sigma Y^{2}-\frac{(\Sigma Y)^{2}}{N}\right)}}
$$


(Miler: 2005:108)

Where:

$r$ : An index of the strength of the linear relationship between $X$ and $Y$.

$\mathbf{X}$ : Independent variable (creativity)

Y: Dependent variable (writing short story skill)

$\mathbf{N}$ : The total subject or sample of the research.

$\Sigma x$ : The total score of students' creativity

$\Sigma y$ :The total score of students' writing short story.

$\Sigma x y$ : The total of multiple score of students' creativity and writing short story skill.

$\boldsymbol{\Sigma} x 2$ : The total of square score of students' creativity

$\boldsymbol{\Sigma} y 2$ : The total of square score of students' writing short story skill.

2. Make conclusion based on the interpretation of the correlation result, whether the $\mathrm{Ha}$ hypothesis accepted or rejected in this study.

\section{RESEARCH FINDING AND DISCUSSION Data Finding}

The data that had been collected by test techniques were creativity and writing tests. The form of creativity test was Verbal Creativity Test from Munandar (2012) that translated into English language, consisted of 30 questions that the scoring rubric can be seen on chapter III. Meanwhile, the form of writing test was essay that consists of an instruction to write a free short story with accepted spelling, grammar, and punctuation. From the data, writer shows the results of the tests in tables as follow;

Table 1.1The score of students' creativity test (X) for the second grade students of MA NW Peseng in IPS:

\begin{tabular}{|l|l|l|}
\hline No. & Name & Score \\
\hline 1. & BS & 87 \\
\hline 2. & BNI & 120 \\
\hline 3. & BRYL & 110 \\
\hline 4. & EW & 70 \\
\hline 5. & EA & 78 \\
\hline 6. & HY & 118 \\
\hline 7 & HD & 132 \\
\hline 8. & I & 140 \\
\hline 9. & IH & 106 \\
\hline 10. & JOJ & 106 \\
\hline 11. & KT & 128 \\
\hline
\end{tabular}

\begin{tabular}{|l|l|l|}
\hline 12. & MSA & 122 \\
\hline 13. & MZM & 94 \\
\hline 14 & NN & 63 \\
\hline 15. & RB & 66 \\
\hline 16. & RS & 135 \\
\hline 17. & RA & 106 \\
\hline 18. & RM & 114 \\
\hline 19. & SA & 60 \\
\hline 20 & SFM & 79 \\
\hline 21. & T & 96 \\
\hline \multicolumn{2}{|l|}{ Total Score $(\Sigma)$} & 2130 \\
\hline
\end{tabular}

Table 1.2 The score of students' writing test (Y) for the second grade students of MA NW Peseng:

\begin{tabular}{|c|c|c|}
\hline No. & Name & Score \\
\hline 1. & BS & 83 \\
\hline 2. & BNI & 85 \\
\hline 3. & BRYL & 73 \\
\hline 4. & EW & 68 \\
\hline 5. & EA & 66 \\
\hline 6. & $\mathrm{HY}$ & 85 \\
\hline 7. & HD & 95 \\
\hline 8. & I & 90 \\
\hline 9. & $\mathrm{IH}$ & 85 \\
\hline 10. & JOJ & 77 \\
\hline 11. & KT & 85 \\
\hline 12. & MSA & 85 \\
\hline 13. & MZM & 90 \\
\hline 14. & $\mathrm{NN}$ & 70 \\
\hline 15. & $\mathrm{RB}$ & 60 \\
\hline 16. & $\mathrm{RS}$ & 90 \\
\hline 17. & RA & 85 \\
\hline 18. & RM & 80 \\
\hline 19. & SA & 60 \\
\hline 20. & SFM & 57 \\
\hline 21. & $\mathrm{~T}$ & 81 \\
\hline \multicolumn{2}{|c|}{ Total Score $(\Sigma)$} & 1650 \\
\hline
\end{tabular}

\section{Discussion}

The main purpose of this research was to find out the correlation between the two variables those are creativity (X) and writing skill (Y). In analyzing and finding the correlation result, the writer determined the result of $\Sigma x y, \Sigma x^{2}$, and $\Sigma y^{2}$. The results of them after the computation were: $\Sigma \mathbf{X}: 2130, \boldsymbol{\Sigma}$ Y: $1650, \Sigma$ XY: $171840, \Sigma \mathbf{X}^{2}: 187626, \Sigma \mathbf{Y}^{2}$ : 
110578. Then, the result can be put on the formula of simple correlation below:

$$
\begin{aligned}
& r_{X Y}=\frac{N \Sigma X Y-(\Sigma X)(\Sigma Y)}{\sqrt{\left(N \Sigma X^{2}\right)-\left(\Sigma X^{2}\right)\left(N \Sigma Y^{2}-\left(\Sigma Y^{2}\right)^{2}\right)}} \\
& r_{X Y=\frac{21.166701-(2130)(1588)}{\sqrt{\left(21.228416-(2130)^{2}\right)\left(21.123268-(1588)^{2}\right)}}} \\
& r_{X Y}=\frac{3500721-3382440}{\sqrt{(4796736-4536900)(2588628-2521744)}} \\
& r_{X Y}=\frac{118281}{\sqrt{(259836)(66884)}} \\
& r_{X Y}=\frac{118281}{\sqrt{1737887}} \\
& r_{X Y}=\frac{118281}{131828} \\
& r_{X Y}=0,897
\end{aligned}
$$

From the computation above, the result of the correlation between the two variables (Students' Creativity and Writing) was 0,829. Before it was compared with $r$ table in degrees of significance 5 and $1 \%$, writer found out the result of the Degree of freedom (df) by following the description below:

$$
\begin{aligned}
& \text { df }=\mathrm{N}-\mathrm{nr} \\
& \quad=21-2 \\
& =19 \\
& \text { note: } \\
& \text { df: Degree of freedom } \\
& \text { N: Number of cases }
\end{aligned}
$$

Number of research variables

After getting the rxy score and $d f$ score, writer compared the rxy score with the rt score with the degree of significance level was $5 \%$ and $1 \%$. When it compared with $5 \%$ degree of significance level, the result was the $r x y>r t$ $(0.829>0.456)$. Meanwhile, when the score of $r x y$ was compared with $r t$ with the degree of significance was $1 \%$, the result was $r x y>r t$ $(0.829>0.575)$.

Due to the rxy score was bigger than the $r t$ score, means that there was a significance correlation between students' creativity and their writing skill at second grade student of MA NW Peseng.

After knowing that there was a significance correlation between students' creativity and their writing skill (Ha was accepted), writer interpreted the correlation coefficient by applying the index of correlation, as suggested by Sugiono (2017:231) as follows:
Table 1.4. The $r$ Score Interpretation

\begin{tabular}{|l|l|}
\hline $\begin{array}{l}\text { The } \boldsymbol{r} \text { score } \\
\text { scale }\end{array}$ & $\begin{array}{l}\text { Interpretation of } \boldsymbol{r} \\
\text { correlation }\end{array}$ \\
\hline $0.80-1.000$ & Very High correlation \\
\hline $0.60-0.799$ & Sufficient correlation \\
\hline $0.40-0.599$ & Fair correlation \\
\hline $0.20-0.399$ & Low correlation \\
\hline $0.00-0.199$ & Very low correlation \\
\hline \multicolumn{2}{|c|}{ Based on the table above, writer } \\
\hline
\end{tabular}
concluded that the correlation between students' creativity and their writing skill had positive correlation with the number of correlation is 0.829 that could be categorized as a very high correlation.

\section{CONCLUSION AND SUGGESTION Conclusion}

Based on the data of the research at the second grade of MA NW Peseng in the academic year of 2019/2020, the researcher made some conclusions as follows:

1. From 21 students, in creativity test there were 3 students who got very excellent score, 6 students got excellent score, 4 students got average score, 1 student got poor score, and the rest (7) students got very poor score. The highest score was 140 and the lowest score was 63.

2. From 21 students, in writing test there was 1 student who got 95 score, 3 students got 90 score, 6 students got 85 score, 1 student got 81 score, and 1 student got 80 score, 1 students got 77 score, 1 student got 73 score, 2 students got 70 scores, 1 student got 68,1 students got 66 score, 2 students got 60 score, and the rests got 57 scores.

3. The researcher found that there was the correlation between two variables (Creativity and Writing), where the result was $r=0.829$ and can be categorized as very high correlation.

\section{Suggestion}

Based on the results of this research, below are some suggestions such for:

1. For the students

Learn and practice more about English language, especially in learning writing do not afraid to combine it with your creativity. 
2. English teachers

English teachers should be more creative when they are teaching English Language. It is because of the way a teacher teaches determines the result of students learning process.

3. This research is discussing about students' skill in writing short story so the next researcher is expected to use another kind of writing that more suitable with students in class.

\section{REFERENCES}

Azizah Yuyun. The Correlation Between Students' Vocabulary Mastery and Their Writing Ability in Descriptive Text. Unpublished, 2017.

Baer, John and James C. Kaufman. Being Creative Inside and Outside The Classroom: How To Boost Your Students' Creativity - and Your Own. Rotterdam: sense publisher, 2012.

Boden A. Margaret. The Creative Mind; Myths and Mechanisms. Rutledge Tyler and Francis group: London and New York, 2004.

Brown Douglas H. Language Assessment; Principles and Classroom Practices. Longman, 2003.

C.R. Kothari. Research Methodology Methods and Techniques (Second Revised Edition). New Age International (p) Ltd, 2004.

Dowdy Shirley et al. Statistics for Research. Wiley Interscience: John Wiley \& Sons, inc. publictin, 2004.

Drapeau Patti. Sparking Student Creativity: Practical Ways to Promote Innovative Thinking and Problem Solving. ASCD; USA, 2014.

Harmer, J. How to Teach Writing. Essex: Pearson Education Limited, 2004.

Heaton. Writing English Language Tests. New York: Longman inc, 1988

Khoir Syamsul. The Relationship Between Students' Creative Thinking Ability and Their Writing Recount Text Skill. Unpublished, 2015.

Lau, Joe Y. F. An Introduction to Critical Thinking and Creativity; Think More,
Think Better. New Jersey: John Wiley \& Sons, 2011.

Madsen S. Harold. Teaching Technique in English As Second Language: Techniques. Testing. Oxford University Press; New York, 1983.

Miller Steve. New Essential Phycology: Experimental Design and Statistics. Taylor \& Francis E-Library, 2005.

Nunan David. Language Teaching Methodology: A Textbooks for Teacher. Prentice hall; Sydney, 1991.

Penke, Lars. Creativity: Theories, Prediction, and Etiology. Unpublished; University of Bielefeld, 2003.

Setiawati Dewi Ayu. The Effect of Star (Select, Teach, Activate, and Revisit) Towards Students' Creativity and Learning Vocabulary at Second Grade Student of SMPN 2 Pringgarata. Unpublished, IKIP Mataram, 2017.

Sugiono. Statistika Untuk Penelitian. Alfbeta, 2017

Sulistio Ajeng Dwi. Correlation of Students' Creativity Interest Towards Writing Ability at Ma Darul Hussaini Sanggeng. Unpublished. Ikip IKIP Mataram, 2018.

Villalba Ernesto. On Creativity: Towards An Understanding of Creativity and Its Measurements. European Commission Joint Research Centre; Italy, 2008.

Zuhro Khairul Lina The Correlation Between Grammar Mastery and Students' Creativity in Writing at The Second Grade Students of SMAN 1 Jonggat in Academic Year 2016/ 2017. Unpublished, IKIP Mataram, 2017. 